\title{
Perancangan Aplikasi Sistem Pakar Penyakit Roseola Dengan Menggunakan Metode Certainty Factor
}

\author{
Lola Fida Putri \\ Program Studi Teknik Informatika, STMIK Budi Darma, Medan, Indonesia \\ Email: lolafidaputri@gmail.com
}

\begin{abstract}
Abstrak-Campak Roseola biasa menyerang bayi dengan penularan dari percikan air liur penderita. Roseola harus cepat diobati karena dapat menyebabkan pembekakan hati dan otak. Penyakit Roseola bagi masyarakat yang ekonominya rendah tidak terlalu diperhatikan karena sering didiagnosa dalam keadaan sakit parah atau akut. Ini dikarenakan menganggap ruam merah pada bayi adalah campak biasa. Diagnosa dini penyakit Roseola merupakan cara baik untuk menghindari akibat yang buruk bagi kesehatan bayi. Sistem Pakar penyakit Roseola mampu membantu masyarakat ekonomi rendah untuk mendiagnosa sendiri penyakit tersebut. Sistem pakar penyakit Roseola merupakan terapan pengetahuan yang didapatkan dari pakar yaitu dokter spesialis penyakit kulit pada anak-anak. Pengolahan gejala-gejala berdasarkan fakta dengan nilai dan perhitungan metode Certainty Factor. Certainty Factor menetukan hasil yang baik dengan pengkombinasian nilai pakar dan nilai user.
\end{abstract}

Kata Kunci: Sistem Pakar, Roseola, Certainty Factor

Abstract-Measles Roseola usually attacks infants with transmission from a sprinkling of sufferers' saliva. Roseola must be treated quickly because it can cause liver and brain inflammation. Roseola's disease for people whose economy is low is not given much attention because it is often diagnosed in severe or acute illness. This is because the red rash in infants is a common measles. Early diagnosis of Roseola's disease is a good way to avoid adverse consequences for the baby's health. The Roseola disease expert system is able to help low-income people to self-diagnose the disease. Roseola's disease expert system is applied knowledge gained from experts, namely specialist dermatologists in children. Processing of symptoms based on facts with the value and calculation of the Certainty Factor method. Certainty Factor determines good results by combining expert values and user values.

Keywords: Expert System, Roseola, Certainty Factor

\section{PENDAHULUAN}

Penyakit Roseola adalah salah satu jenis dari campak akan tetapi berbeda dengan penyakit campak biasanya. Campak Roseola biasanya menyerang bayi dengan penularan dari percikan air liur penderita. Campak Roseola berasal dari virus herpest tipe 6 dan 7 dan Sebenarnya campak Roseola dapat sembuh dengan sendirinya jika penderita memiliki antibodi yang baik. Bagi penderita yang memiliki antibodi yang kurang baik harus diobati dengan cepat karena dapat menyebabkan pembekakan hati dan otak. Adapun Gejala yang timbul, seperti demam selama 3 hari berkisar $39-40^{\circ} \mathrm{C}$, dan setelah demam selesai muncul ruam kemerahan, diare, batuk, pilek, radang tenggorokan, pembesaran kelenjar limfe (kelenjar getah bening) di kepala belakang, timbul bercak merah pada langit-langit mulut dan daerah ovula (vaginal).

Hidup sehat salah satu harapan dalam keluarga. orangtua yang baik selalu memperhatikan kesehatan anakanaknya dan mengajarkan untuk selalu menjaga kesehatan. Akan tetapi ada juga orangtua yang terlalu sibuk dengan pekerjaannya sehingga kurang memperhatikan kesehatan anak-anaknya. Sikap lalai orangtua dapat menyebabkan penyakit yang diderita anak-anak menjadi parah atau menyebabkan kematian. Cara yang baik untuk mengatasi masalah orangtua yang sibuk dengan pekerjaannya adalah orangtua dapat menggunakan salah satu aplikasi dari sistem pakar untuk mengetahui penyakit yang diderita anaknya.

Sistem Pakar (Expert System) digunakan dengan bantuan perangkat komputer untuk memberikan keputusan atas suatu masalah yang spesifik dan terbatas. Sistem pakar berupa teknologi inteligensi buatan dari pengetahuan (knowledge) dan pengalaman dari hasil eksperimen para ahli atau pakar di bidangnya. Pengetahuan pakar yang diwujudkan dalam bentuk aplikasi tingkat pemecahannya dapat sama dengan para pakarnya, sehigga pengguna dapat berinteraksi dengan dengan komputer sistem pakar tanpa harus menjumpai pakarnya. Seperti seorang yang menderita penyakit tertentu dapat menggunakan sistem pakar yang sesuai atau menyamai gejala penyakitnya untuk mendapatkan solusi dan saran dari sistem pakar.Contoh Sistem Pakar untuk deteksi penyakit ruam kulit menggunakan metode Bayes dengan kesimpulan hasil pengujian yaitu dari enam gejala yang ada, maka nilai probabilitas terbesar ada pada penyakit Roseola yaitu 0,00309716, maka kemungkinan pasien terkena penyakit Roseola dan metode Bayes cukup akurat dalam menentukan diagnosa dari penyakit ruam kulit untuk lima penyakit yang diujikan[1].

Metode Certainty Factor salah satu metode yang sering digunakan dalam penelitian untuk sistem pakar selain metode Bayes. Certainty Factor dapat membuktikan apakah suatu fakta itu pasti ataukah tidak pasti yang berbentuk metric. Penggunaan metode Certainty Factors ini sangatlah mudah dengan penentuan bobot yang diberikan, dan dikalkukasi berdasarkan fakta-fakta yang muncul sebagai gejala. Hal yang perlu diperhatikan dalam metode Certainty Factors ini adalah pemberian nilai bobot terhadap gejala yang ditimbulkan akan berpengaruh terhadap besaran hasil kesimpulan yang diperoleh. Tidak menutup kemungkinan bagi pengembangan lanjut atas 
metode Certainty Factors ini dengan kombinasi rule yang lebih kompleks sehingga kompleksitas diagnosis dapat memberikan hasil yang lebih memuaskan[2].

\section{METODE PENELITIAN}

\subsection{Sistem Pakar}

Sistem Pakar adalah sistem berbasis komputer yang menggunakan pengetahuan, fakta, dan teknik penalaran dalam memecahkan masalah, yang biasanya hanya dapat diselesaikan oleh seorang pakar dalam bidang tertentu [3]..

\subsection{Certainty Factor}

Certainty Faktor kepastian marupakan cara dari penggabungan kepercayaan dan ketidakpercayaan dalam bilangan yang tunggal. Dalam certainty theory, data-data kualitatif dipresentasikan sebagai derajat keyakinan (degree of belief). Ada dua langkah dalam perepresentasian data-data kualitatif. Langkah pertama adalah kemampuan untuk mengekspresikan derajat keyakinan tersebut dalam sistem pakar. Dalam mengekpresikan derajat kepastian, certainty factor untuk mengasumsikan derajat kepastian seorang pakar terhadap suatu data. Certaity factor memperkenalkan konsep belief/keyakinan dan disbelief/ketidakyakinan [4]

Konsep ini kemudian diformulasikan dalam rumus dasar sebagai berikut:

$C F[H, E]=M B[H, E]-M D[H, E]$

$C F[H, E]_{1}=C F[H]^{*} C F[E]$

Keterangan :

$C F \quad=$ Certainty factor (faktor kepastian) dalam hipotesa $\mathrm{H}$ yang dipengaruhi oleh fakta $\mathrm{E}$.

$M B=$ Measure of belief (tingkat keyakinan) merupakan ukuran dalam kepercayaan hipotesa $\mathrm{H}$ dipengaruhi oleh fakta $\mathrm{H}$.

$E \quad=$ Evidence (peristiwa atau fakta)

$C F(E) \quad=$ Certainty factor evidence E yang dipengaruhi oleh evidence e

$C F(H) \quad=$ Certainty factor hipotesis dengan asumsi evidence diketahui dengan pasti, yaitu ketika $\mathrm{CF}(\mathrm{E}, \mathrm{e})=1$

$C F(H, E)=$ Certainty factor hipotesis yang dipengaruhi oleh evidence e Jika semua evidence pada antecedent diketahui dengan pasti.

Certainty factor untuk kaidah yang serupa (Similiary concluded rules)

$C F_{\text {combine }} C F[H, E]_{1,2}=C F[H, E]_{1}+C F[H, E]_{2} *\left(1-C F[H, E]_{1}\right)$

$C F_{\text {combine }} C F[H, E]_{\text {old } 3}=C F[H, E]_{\text {old }}+C F[H, E]_{3} *\left(1-C F[H, E]_{\text {old }}\right)$

\subsection{Penyakit Roseola}

Human herpesvirus type 6 (HHV-6) merupakan penyebab terbanyak Roseola Infantum atau exanthema subitum(45-86\%), yang merupakan penyakit pada bayi dengan ruam dan disertai dengan infeksi saluran nafas akut dan kelainan serebral. Gejala ini harus dibedakan dengan penyakit lain pada penderita normal dan harus dicari padanannya pada penderita dengan defisiensi imun. Virus ini umumnya hanya menimbulkan gejala klinik yang ringan, namun bisa bersifat laten dan sering dikaitkan dengan gejala klinik kelainan otak termasuik multiple sclerosis. Infeksi Primer HHV-6 didapat dari kasus kontak dan sumber infeksi primer HHV-6 hampir selalu tak diketahui dengan inkubasi sekitar 10 hari. Manifestasi klinis sangat bervariasi; mayoritas berupa Roseola dan demam tinggi akut (39 - 40o C), berlangsung 3 - 6 hari. Demam seiring dgn viremia; disertai gejala lethargy, anoreksia atau beberapa tak terganggu oleh demam tinggi tersebut Biasanya diagnosis awal pend inf primer HHV6 adalah demam tanpa sebab yang jelas disertai (kadang) otitis media. Human herpesvirus type 7 (HHV-7) mirip dengan HHV 6 dan gejala klinik yang ditimbukan pun mirip, dengan prevalensi lebih rendah (10-31\%) [7].

\section{ANALISA DAN PEMBAHASAN}

Tahapan analisis terhadap suatu sistem dilakukan sebelum tahapan perancangan, karena hal ini agar sistem pakar yang dirancang sesuai dengan masalah yang diselesaikan. Pembuatan sistem pakar mengacu pada user interface yang akan dirancang. Tepatnya sistem pakar penyakit Roseola dan metode Certainty Factors untuk pendefinisian harus sesuai input data, proses, dan output yang hasilkan dapat memberikan keterangan dari input data yang dimasukkan. Data yang dimaksud berdasarkan hubungan-hubungan permasalahan yang berkaitan satu sama lain. Sebagai data input adalah penyakit Roseola dengan gejala-gejala Roseola Gejala, yaitu: Demam, Tinggi Demam antara 39-40 ${ }^{\circ} \mathrm{C}$, Kejang-kejang, Ruam kemerahan muncul setelah demam turun, Diare, Batuk, Pilek, Radang tenggorokan, Pembesaran kelenjar limfe di kepala belakang, Nakayamaís spot, Nafsu makan berkurang, dan Kelopak mata membengkak.

Tabel 1. Tabel Kode dan Nama Jenis Gejala

\begin{tabular}{lll}
\hline No & Kode & Nama Jenis Gejala \\
\hline 1 & G001 & Demam
\end{tabular}




\begin{tabular}{lll}
2 & G002 & Tinggi Demam antara $39-40{ }^{\circ} \mathrm{C}$ \\
3 & G003 & Kejang-kejang \\
4 & G004 & Ruam kemerahan muncul setelah demam turun \\
5 & G005 & Diare \\
6 & G006 & Batuk \\
7 & G007 & Pilek \\
8 & G008 & Radang tenggorokan \\
9 & G009 & Pembesaran kelenjar limfe di kepala belakang \\
10 & G010 & Nakayamaís spot \\
11 & G011 & Nafsu makan berkurang \\
12 & G012 & Kelopak mata membengkak \\
\hline
\end{tabular}

Langkah pertama pakar memberikan sejumlah pertanyaan mengenai gejala Roseola kepada user sebagai berikut:

1. Apakah bayi mengalami demam ?
a. tidak mungkin
b. mungkin
c. kemungkinan besar
d. pasti
e. sangat pasti

User menjawab d. pasti, nilai 0,8

2. Apakah demam tinggi antara $39-40{ }^{\circ} \mathrm{C}$ ?
a. tidak mungkin
b. mungkin
c. kemungkinan besar
d. pasti
e. sangat pasti

User menjawab d. pasti, nilai 0,8

3. Apakah bayi mengalami Kejang-kejang ?
a. tidak mungkin
b. mungkin
c. kemungkinan besar
d. pasti
e. sangat pasti
User menjawab a.tidak mungkin, nilai 0,2

4. Apakah ada ruam kemerahan muncul setelah demam turun ?
a. tidak mungkin
c. kemungkinan besar
b. mungkin
d. pasti

e. sangat pasti

User menjawab d. pasti, nilai 0,8

5. Apakah bayi mengalami Diare ?
a. tidak mungkin
b. mungkin
c. kemungkinan besar
d. pasti
e. sangat pasti

User menjawab b. mungkin, nilai 0,4

6. Apakah bayi mengalami Batuk ?
a. tidak mungkin
b. mungkin
c. kemungkinan besar
d. pasti
e. sangat pasti

User menjawab b. mungkin, nilai 0,4

7. Apakah bayi mengalami Pilek ?
a. tidak mungkin
b. mungkin
c. kemungkinan besar
d. pasti

e. sangat pasti

User menjawab b. mungkin, nilai 0,4

8. Apakah terdapat Radang Tenggorokan ?
a. tidak mungkin
c. kemungkinan besar
b. mungkin
d. pasti

e. sangat pasti

User menjawab b. mungkin, nilai 0,4

9. Apakah terdapat Pembesaran kelenjar limfe di kepala belakang bayi ?
a. tidak mungkin
b. mungkin
c. kemungkinan besar
d. pasti
e. sangat pasti
User menjawab b. mungkin, nilai 0,4

10. Apakah terdapak bercak merah pada langit-langit mulut dan daerah ovula (Nakayamaís spot)?
a. tidak mungkin
b. mungkin
c. kemungkinan besar
d. pasti
e. sangat pasti 
User menjawab b. mungkin, nilai 0,4

11. Apakah nafsu makan bayi berkurang ?
a. tidak mungkin
b. mungkin
c. kemungkinan besar
d. pasti
e. sangat pasti
User menjawab a. tidak mungkin, nilai 0,2

12. Apakah Kelopak mata bayi membengkak ?
a. tidak mungkin
b. mungkin
c. kemungkinan besar
d. pasti
e. sangat pasti
User menjawab a. tidak mungkin, nilai 0,2

Langkah kedua kaidah-kaidah yang baru tersebut di hitung nilai $\mathrm{Cfnya}$ dengan mengalikan $\mathrm{CF}_{\text {pakar }}$ dengan $\mathrm{CF}_{\mathrm{user}}$ $\mathrm{CF}[\mathrm{H}, \mathrm{E}]_{1}$

$$
\begin{aligned}
& =\mathrm{CF}[\mathrm{H}]_{1} * \mathrm{CF}[\mathrm{E}]_{1} \\
& =0.8 * 0.6
\end{aligned}
$$

$$
\begin{aligned}
& =0.48 \\
& \mathrm{CF}[\mathrm{H}, \mathrm{E}]_{2} \quad=\mathrm{CF}[\mathrm{H}]_{2} * \mathrm{CF}[\mathrm{E}]_{2} \\
& =0,8 * 0.6 \\
& =0.48 \\
& \mathrm{CF}[\mathrm{H}, \mathrm{E}]_{3}=\mathrm{CF}[\mathrm{H}]_{3} * \mathrm{CF}[\mathrm{E}]_{3} \\
& =0.2 * 0.2 \\
& =0.04 \\
& \mathrm{CF}[\mathrm{H}, \mathrm{E}]_{4} \quad=\mathrm{CF}[\mathrm{H}]_{4} * \mathrm{CF}[\mathrm{E}]_{4} \\
& =0.8 * 0.4 \\
& =0.32 \\
& \mathrm{CF}[\mathrm{H}, \mathrm{E}]_{5}=\mathrm{CF}[\mathrm{H}]_{5} * \mathrm{CF}[\mathrm{E}]_{5} \\
& =0.4 * 0.2 \\
& =0.08 \\
& \mathrm{CF}[\mathrm{H}, \mathrm{E}]_{6}=\mathrm{CF}[\mathrm{H}]_{6} * \mathrm{CF}[\mathrm{E}]_{6} \\
& =0.4 * 0.2 \\
& =0.08 \\
& \mathrm{CF}[\mathrm{H}, \mathrm{E}]_{7}=\mathrm{CF}[\mathrm{H}]_{7} * \mathrm{CF}[\mathrm{E}]_{7} \\
& =0.4 * 0.2 \\
& =0.4 * 0.2 \\
& =0.08 \\
& =0.4 * 0.2 \\
& =0.08 \\
& =0.2 * 0.2 \\
& =0.04 \\
& =0.2 * 0.2 \\
& =0.04
\end{aligned}
$$

Langkah yang terakhir adalah mengkombinasikan nilai $\mathrm{CF}$ dari masing-masing kaidah. Berikut kombinasi $\mathrm{CF}_{1}$ dengan $\mathrm{CF}_{2}$ :

$$
\begin{aligned}
& \mathrm{CF}_{\text {combine }} \mathrm{CF}[\mathrm{H}, \mathrm{E}]_{1,2} \\
& =0.48+0.48 *(1-0.48) \\
& =0.48+0.2496 \\
& =0.7296_{\text {old }} \\
& \mathrm{CF}_{\text {combine }} \mathrm{CF}[\mathrm{H}, \mathrm{E}]_{\text {old }, 3}=\mathrm{CF}[\mathrm{H}, \mathrm{E}]_{\text {old }}+\mathrm{CF}[\mathrm{H}, \mathrm{E}]_{3} *\left(1-\mathrm{CF}[\mathrm{H}, \mathrm{E}]_{\text {old }}\right) \\
& =0.7296+0.04(1-0.7296) \\
& =0.7296+0.010816 \\
& =0.740416_{\text {old } 2} \\
& \mathrm{CF}_{\text {combine }} \mathrm{CF}[\mathrm{H}, \mathrm{E}]_{\mathrm{old} 2,4}=\mathrm{CF}[\mathrm{H}, \mathrm{E}]_{\mathrm{old} 2}+\mathrm{CF}[\mathrm{H}, \mathrm{E}]_{4} *\left(1-\mathrm{CF}[\mathrm{H}, \mathrm{E}]_{\mathrm{old} 2}\right) \\
& =0.740416+0.32 *(1-0.912) \\
& =0.740416+0.08306688 \\
& =0.82348288_{\text {old } 3}
\end{aligned}
$$


JSON Volume 1, Nomor 2, Januari 2020

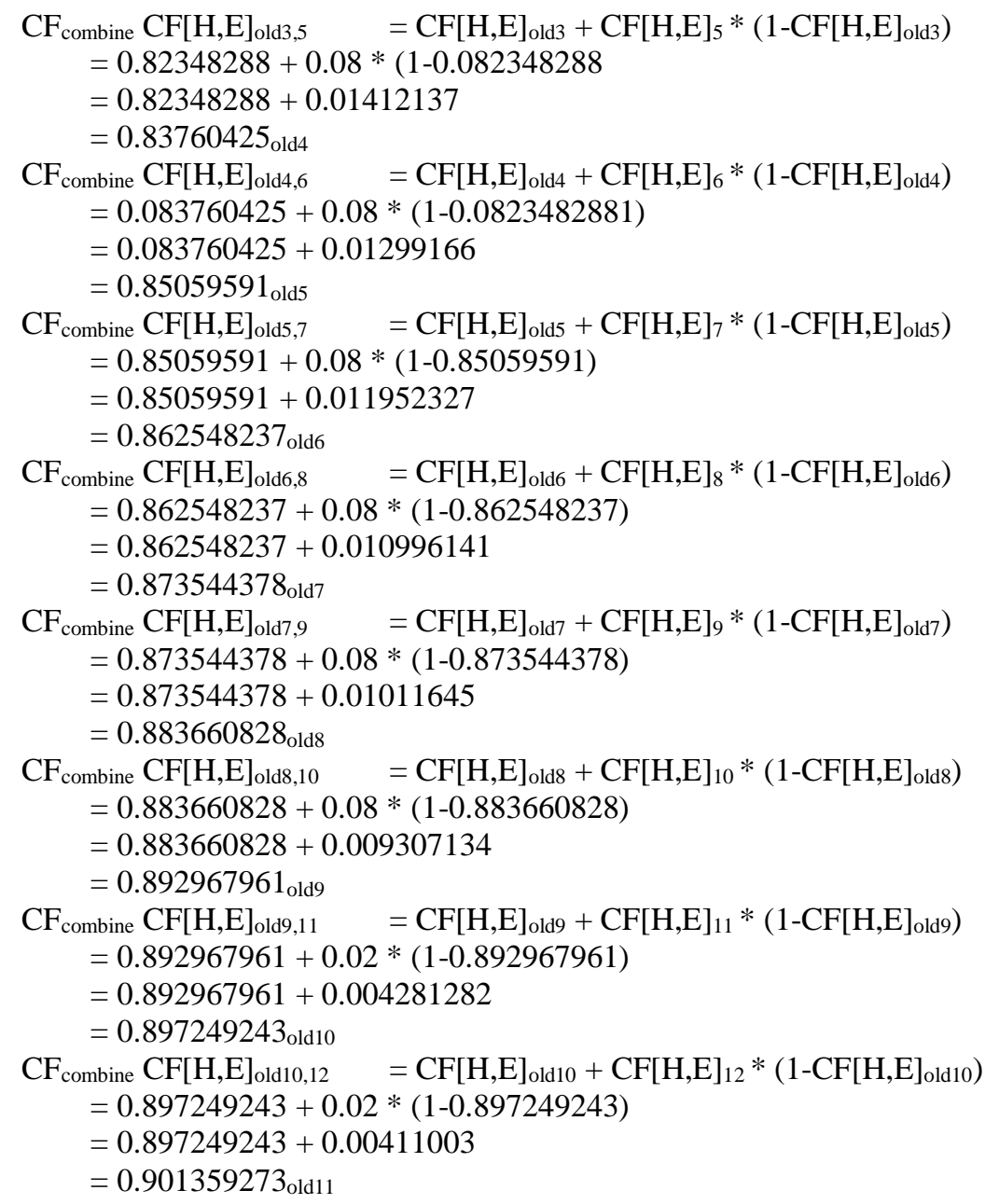

Pencarian hasil kombinasi diurutkan seperti pada tabel di bawah

Tabel 2. Perbandingan nilai kombinasi CF

\begin{tabular}{rlll}
\cline { 2 - 4 } & \multicolumn{1}{c}{ M1 } & \multicolumn{1}{c}{ M2 } & \multicolumn{1}{c}{ M3 } \\
\cline { 2 - 4 } & 0.7296 & 0.8128 & 0.8704 \\
& 0.740416 & 0.820288 & 0.880768 \\
& 0.82348288 & 0.93530368 & 0.95707648 \\
& 0.83760425 & 0.945655091 & 0.970812006 \\
& 0.85059591 & 0.954350277 & 0.980152164 \\
& 0.862548237 & 0.961654232 & 0.986503472 \\
& 0.873544378 & 0.967789555 & 0.988662916 \\
Hasil Akhir $\rightarrow \rightarrow$ & 0.883660828 & 0.972943226 & 0.99047685 \\
& 0.892967961 & 0.97727231 & 0.993524258 \\
& 0.897249243 & 0.978181418 & 0.994042317 \\
\cline { 2 - 4 }
\end{tabular}

Dari tabel di atas pada kombinasi ke sebelas disusun seperti berikut :

Roseola Ringan $=0.901359273$

Roseola Sedang $=0.979054161$

Roseola Berat $=0.994518932$

Maka tingkat keyakinan dari pada jawaban user didiagnosa sebagai Roseola Berat. Solusi penderita terkena Roseola berat yaitu, segera bawa ke dokter atau Rumah Sakit untuk penanganan lebih lanjut. Beri banyak cairan untuk mencegah dehidrasi akibat demam tinggi.

\subsection{Implementasi}

Hasil pengujian program menampilkan hasil output dari sebuah input data pada aplikasi yang telah siap. Untuk melakukan input pada halaman konsultasi yaitu dengan cara pilih jawaban yang menurut pengguna sesuai dengan kondisi yang dialami bayinya.. Setelah memilih salah satu jawaban hingga 12 pertanyaan pengguna dapat menekan tombol Proses dan menunggu halaman hasil keluar. Berikut ini adalah gambar tampilan halaman Konsultasi. 


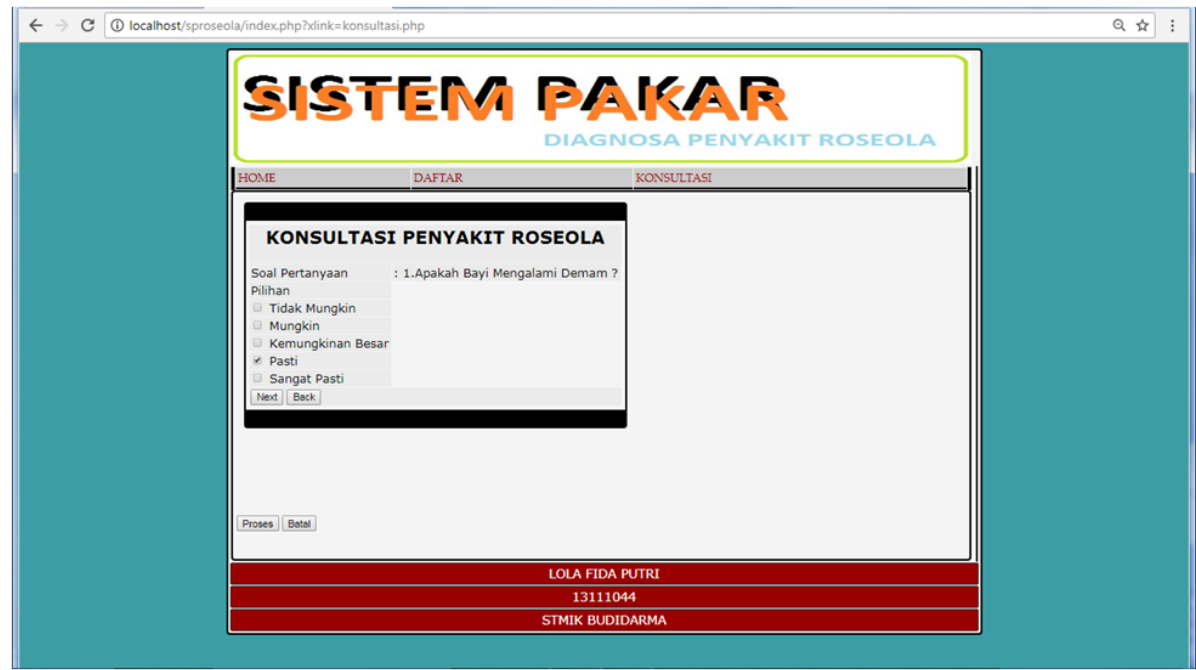

Gambar 1. Input Pada Halaman Konsultasi

Tampilan output adalah tampilan hasil dari proses metode certainty factor pada sistem pakar penyakit Roseola. Gambar 2. di bawah ini adalah tampilan output yang memuat nama bayi pengguna, hasil penyakit Roseola, dan solusi yang diberikan yang berkaitan dengan hasil.

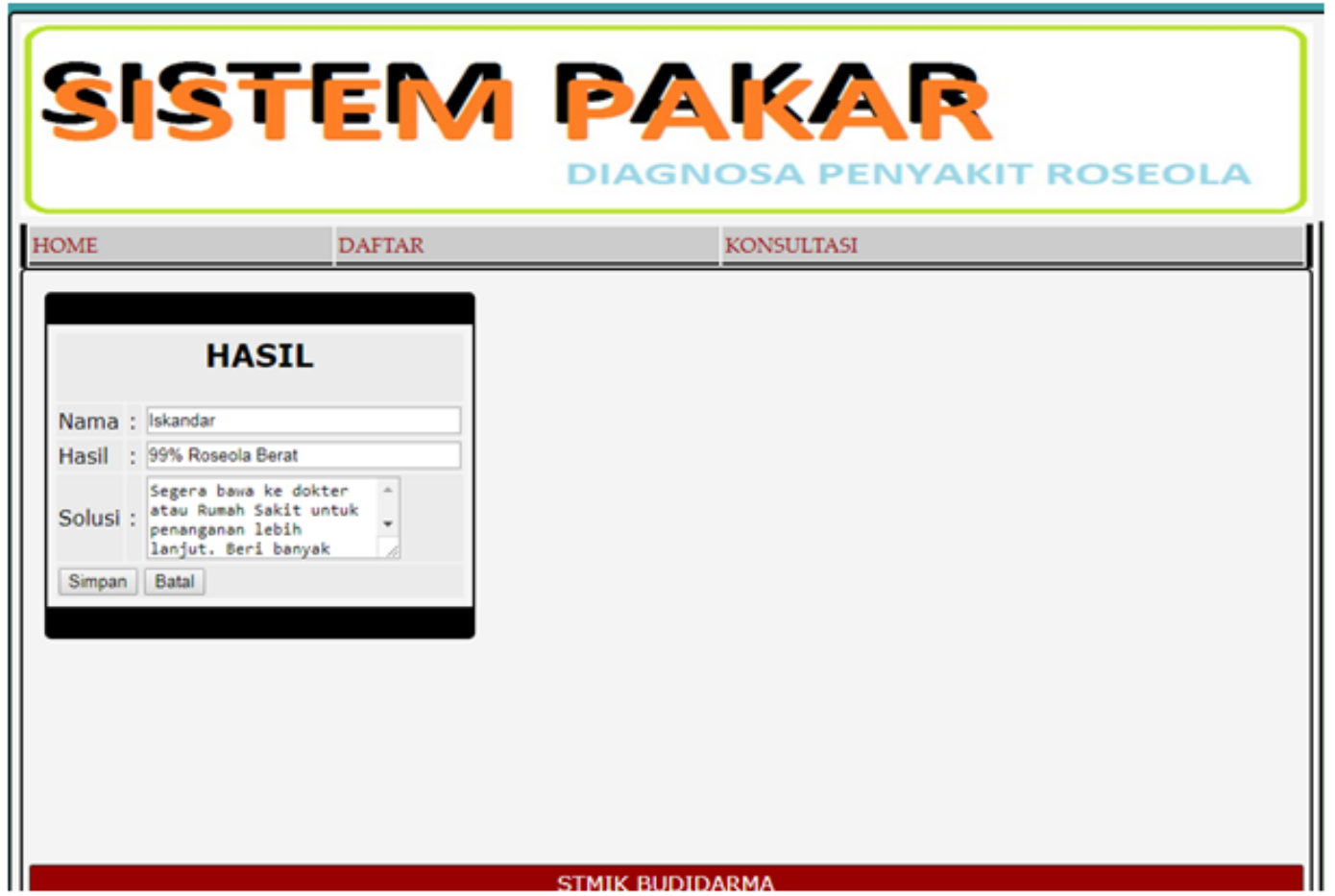

Gambar 2. Tampilan Hasil Diagnosa Penyakit Roseola

\section{KESIMPULAN}

Dari hasil yang penulis lakukan terhadap penelitian ini penulis dapat menarik beberapa kesimpulan yang terkait dengan proses penelitian maupun dengan isi dari penelitian itu sendiri. Adapun kesimpulan - kesimpulan tersebut adalah sebagai berikut :

1. Gejela-gejala penyakit Roseola terdiri dari dua belas gejala keseluruhannya, namun penyakit Roseola dapat juga tidak mengidikasikan keseluruhan dari gejala-gejala, karena itu penyakit Roseola dibagi menjadi tiga yaitu, Roseola ringan, Roseola sedang, dan Roseola berat.

2. Pendiagnosaan penyakit Roseola dilakukan pengguna dengan menjawab pertanyaan-pertanyaan pilihan ganda. Setiap jawaban akan dibandingkan dengan fakta yang tersimpan dalam mesin inferensi sistem pakar.

3. Perancangan sistem pakar penyakit Roseola berbasis web dapat digunakan siapa saja baik secara online

\section{REFERENCES}


USON Volume 1, Nomor 2, Januari 2020

e-ISSN 2685-998X

DOI 10.30865/json.v1i2.1956

[1] Z. Yunizar, 2017, Sistem Pakar Untuk Deteksi Penyakit Ruam Kulit Menggunakan Metode Bayes, Variasi : Majalah Ilmiah Universitas Almuslim p55-62, ISSN 2085-6172.

[2] S. Rohajawati dan R. Supriyati, 2010, Sistem Pakar: Diagnosis Penyakit Unggas Dengan Metode Bayes, Jurnal CommIT, Bogor

[3] Kusrini,2008.Aplikasi Sistem Pakar. Penerbit Andi, Yogyakarta

[4] M. Arhami, 2005. Konsep Dasar Sistem Pakar. Penerbit Andi. Yogyakarta 